\title{
PARTY MEMBERS AND ACTIVISTS
}

DOI: 10.20901/an.13.09

Z

bornik Party Members and Activists, koji uređuju politologinje Emilie van Haute, predavačica na Slobodnom sveučilištu u Bruxellesu, i Anika Gauja, izvanredna profesorica Sveučilišta u Sydneyu, dio je serijala knjiga pod naslovom Routledge Research on Social and Political Elites. Zbornik sadrži dvanaest poglavlja na ukupno 227 stranica napisanih od ukupno 21 istraživača. Uvodno i zaključno poglavlje potpisuju urednice zajedno, dok je preostalih deset poglavlja strukturirano kao doprinos autora koji su stranačko članstvo istraživali u pojedinim državama.

Uvodno poglavlje Introduction: Party membership and activism (1-16) van Haute i Gauja posvetile su objašnjavanju važnosti zbornika u perspektivi suvremenih istraživanja stranačkog članstva. Nastojanje je knjige odmaknuti se od klasičnog pogleda na članstvo političkih stranaka koje je podrazumijevalo krute teorijske modele, prema istraživanju empirijske zbilje. Autorice tvrde da su iskustva članstva izrazito različita, a posebno je to činjenica, tvrde, u pogledu načina na koje članovi sudjeluju u radu stranaka. Tko poznaje druge radove urednica znat će kako su one sklonije shvaćati političke stranke prije kao orga- nizacije transformacije nego kao krute organizacije nesklone prilagodbi. Važno je, zato, cjelinu zbornika promatrati kao dodatak doista dugoj raspravi o značenju i budućnosti političkih stranaka kao članskih organizacija. Teza o propasti stranaka sama po sebi, tvrde urednice, ne odgovara na pitanja tko u strankama ostaje, tko odlazi, te na kraju je li masovno članstvo doista presudno za organizacijski opstanak neke političke stranke.

Urednice s čitateljem odmah na početku sklapaju dogovor da će knjigu usmjeriti na nekoliko važnih pitanja. Što stranačko članstvo znači za demokraciju danas? Tko su ljudi koji se učlanjuju u političke stranke, tko su članovi, a tko aktivisti? Zašto to čine, s kojim motivima? Kakvi su im stavovi (s obzirom na vlastito pozicioniranje na skali lijevodesno i niz drugih indikatora)? Te, naposljetku, kakav je karakter njihovog političkog aktivizma, kako se angažiraju u svojim strankama, koliko često te koliko intenzivno? I dok je slika o tome tko se, zašto i s kojim stavovima učlanjuje u stranke danas znatno potpunija (makar u komparativnom pogledu još uvijek nedostatna), o prirodi sudjelovanja članova još se uvijek zna vrlo malo. S obzirom na to i ovaj je prikaz strukturiran sa svr- 
hom prikazivanja najzanimljivijih odgovora na ova pitanja. Zbog ograničenosti prostora cijeli je niz podataka o pojedinim strankama bilo nemoguće uključiti.

Urednice u uvodnom poglavlju nude pregled ključnih teorijskih problema u istraživanjima članstva političkih stranaka, te ih stavljaju u kontekst važnosti stranačkog članstva kao društvenog i političkog fenomena. Osim toga prezentiraju neka metodološka ograničenja $s$ kojima se suočavaju istraživači stranačkog članstva te nude osvrt na komparativni analitički okvir strukture zbornika. Metodološka ograničenja počinju već kod samog prikupljanja podataka. Subjektivna mjerenja kao što su ona kod kojih se od građana traži da se izjasne kao članovi ili nečlanovi neke stranke tako, primjerice, otežavaju komparaciju $\mathrm{u}$ više zemalja i rezultiraju vrlo malim uzorcima članova s kojima je teško raditi daljnje analize. Niti suvremena objektivna mjerenja nisu savršen izvor podataka pa češće možemo govoriti o nepotpunim registrima, nego o egzaktnim brojevima. Jedan od razloga za to je i nepovjerenje koje stranke imaju prema istraživačima političkih stranaka. Metodološka kolebanja nastavljaju se i nakon faze prikupljanja podataka pri analizi podataka, komparaciji stranaka ili zemalja, te interpretaciji u odnosu na druge opažene stranke ili demokracije.

Knjiga u nastavku donosi recentne studije članstva deset industrijskih demokracija (Španjolska, Belgija, Kanada, Danska, Njemačka, Izrael, Italija, Nizozemska, Norveška i Velika Britanija) strukturirane u dva dijela. Prvi dio obuhvaća analizu kriterija, uvjeta, prava i obveza za stranačko članstvo u ukupno 77 političkih stranaka. Drugi dio donosi dosad najsustavniji prikaz podataka o karakteristikama članstva 57 najrelevan- tnijih stranaka u svijetu, koje pripadaju cijelom nizu stranačkih obitelji.

Poglavlje Party membership in Spain and congress delegates (17-33) napisala je skupina pet španjolskih istraživača. Montserrat Baras je stručnjakinja za regionalističke stranke i decentralizaciju, Oscar Barberà i Astrid Barrio su oboje izvanredni profesori Sveučilišta u Valenciji i dobitnici nagrade za najbolje doktorske disertacije Španjolskog udruženja političkih znanosti. Četvrti koautor, ujedno i glavni tajnik spomenutog udruženja, njihov je kolega predavač na Sveučilištu u Valenciji, Juan Rodríguez-Teruel. Uz njih koautorica ovog poglavlja je i doktorska studentica Autonomnog Sveučilišta u Barceloni Patricia Correa. Oni su analizirali ankete koje su ispunjavali delegati stranačkih konferencija osam španjolskih stranaka. Ta razlika u odnosu na ostala poglavlja koja analiziraju ukupno stranačko članstvo rezultat je duge španjolske tradicije istraživanja članstva koja je za uzorak uvijek uzimala upravo stranačke delegate.

Španjolski regulatorni okvir ne predviđa da stranka mora imati članove, ali predviđa minimalni set prava i obveza koji je stranka obvezna osigurati članstvu. Kako bi pojedinac postao član mora stranci plaćati članarinu te navršiti određene godine života. Uglavnom je riječ o pojedinačnom članstvu, a u nekoliko slučajeva i o pridruženom, kolektivnom obliku članstva. U određenom broju analiziranih stranaka članovi su obvezni pridržavati se ideoloških načela, statuta ili izbornog programa stranke. Neke stranke zahtijevaju preporuku dotadašnjih članova, a neke imaju čak i probni rok. Gotovo sve stranke omogućuju upis u registar simpatizera. Koliko god to djelovalo progresivno, autori napominju kako stranke često stapaju popise pristaša i punopravnih članova u isti 
registar. To posljedično dovodi u pitanje točnost podataka o broju članova.

Analiza uključuje i ispitivanje unutarstranačkih mehanizama demokratičnosti. Autori su pokazali kako sve stranke omogućuju svojim članovima informiranost o stranačkim aktivnostima, uspostavljanje kontakata, kontrolu nad stranačkim predstavnicima i obvezuju stranke na obavljanje socijalizacijske funkcije. U svim strankama članovi imaju pravo kandidiranja na pojedine pozicije ako ispunjavaju uvjete za njih. Neke stranke svojim članovima uvjetuju sudjelovanje u svakodnevnim aktivnostima stranke, no samo manjina stranaka dopušta svim članovima sudjelovanje u procesima odlučivanja o ulasku stranke u koalicije. Vrlo je zanimljivo da gotovo sve španjolske stranke članovima omogućuju eksplicitno pravo sudjelovanja u oblikovanju izbornih programa. Također, Španjolska bilježi povećanje u broju članova što ju pozicionira kao odstupajući slučaj uvriježenoj tezi o propasti stranaka. Autori nude detaljan pregled povijesnih i kontekstualnih zbivanja koja ovakvo odstupanje objašnjavaju.

U vlastitoj analizi anketa provedenih u osam stranaka autori ovog poglavlja ustanovili su da je dominantan motiv za učlanjenje u španjolske stranke ideološke prirode, dok su materijalni razlozi najmanje zastupljeni. Stranačko članstvo u Španjolskoj u većini čine sredovječni muškarci, uglavnom više i visoko obrazovani. Članovi stranaka ljevice i lijevog centra uglavnom su zaposleni u javnom sektoru, dok su članovi stranaka desnice i desnog centra uglavnom zaposleni u privatnom sektoru, s nekoliko stranaka iznimke. Najsnažnija ideološka polarizacija u članstvu vidi se u stupnju (i)religioznosti. Uzevši u obzir napomenu autora da su jedinice analize delegati (od kojih se i očekuje viša razina aktivnosti) rezultati su pokazali relativno visoku razinu aktivnosti. Delegati nacionalnih stranaka aktivniji su, jer su i selekcijski procesi za njihov odabir stroži. U manjim strankama konferencije sačinjava cjelokupno članstvo. Razlike su nešto manje kad se uspoređuje samo aktivnost na lokalnim sastancima gdje su sve stranke pokazale vrlo visok stupanj prisutnosti članova.

Jedna od urednica, Emilie van Haute priredila je treće poglavlje Party membership in Belgium: From the cradle to the grave? (34-49). U Belgiji ne postoji izvanjska regulacija stranaka. Jedini zakon koji regulira stranke odnosi se na javno financiranje i on prepoznaje političku stranku u svakoj političkoj skupini koja ima izabrane predstavnike u tijelima vlasti. Uvjet za članstvo su plaćanje članarine i minimalna dob. Dodatno, velik broj stranaka traži ekskluzivnost (s izuzetkom nekih stranaka koje dopuštaju članstvo u sestrinskim strankama) i pristajanje uz temeljne principe stranke. Manji dio stranaka omogućava upis u popis simpatizera. Uglavnom se upis u članstvo obavlja u lokalnoj teritorijalnoj organizaciji, međutim zanimljivo je da nekoliko belgijskih stranaka omogućuje izravni upis u članstvo na višoj razini regionalnoj ili nacionalnoj.

Što se tiče prava i obveza članova samo dvije stranke ne dopuštaju svim članovima sudjelovanje na konferencijama i u njima konferencije predstavljaju delegati nižih teritorijalnih razina. $U$ svima, osim u jednoj stranci, svi članovi imaju pravo biranja vođe stranke. Četiri stranke dopuštaju svim članovima sudjelovanje u selekcijskom procesu kandidacijskih lista, šest omogućuju članovima sudjelovanje u procesu oblikovanja izbornog programa, a dvije čak i glasovanje o njegovoj završnoj verziji. Autorica navodi i primjer stranke koja u svo- 
jem statutu propisuje obvezu sudjelovanja u kolektivnoj deliberaciji, razvoju političkih načela i programa stranke, i aktivnu uključenost u život organizacije.

U pogledu broja članova van Haute pokazuje kako je pad moguće uočiti tek od 1990-ih godina. U usporedbi s drugim državama Belgija je još uvijek u vrhu zemalja članica Europske unije po masovnosti članstva i bilježi znatno sporiji pad u longitudinalnoj perspektivi. Osim toga, pad bilježe samo nekadašnje omasovljene "stranke stupovi" - socijalisti i demokršćani. Zeleni, regionalisti i ekstremna desnica suprotno općem trendu bilježe porast stranačkog članstva. Van Haute je analizirala ankete četiriju stranaka - dviju frankofona (socijaldemokrati - PS i zeleni - Ecolo) te dviju flamanskog govornog područja (liberalni demokrati - OpenVLD i demokršćani - CD\&V). Ovakvim uzorkovanjem omogućila je dva tipa usporedbe: s obzirom na stranačke obitelji i s obzirom na tip stranačke organizacije. Rezultati su pokazali da među motivima za učlanjenje prevladavaju ideološki razlozi, slijede razlozi procesne skupine dok su materijalni razlozi prijavljivani u najmanjem postotku. Podaci koji govore o društvenim i demografskim karakteristikama članova u skladu su s očekivanim. Većinom je riječ o sredovječnim, visoko školovanim i profesionalno aktivnim muškarcima. Analiza je potvrdila snažnu društvenu polarizaciju belgijskog društva i u odnosu na strukturu članova i na njihove stavove, posebice $\mathrm{u}$ dvjema strankama stupovima (PS i CD\&V). Ecolo se pokazao kao odstupajući primjer s izrazito aktivnim članstvom šarolikih stavova na ljestvici lijevo-desno.

Četiri velike, kanadske, federalne stranke (Konzervativnu, Novu demokratsku - NDP, Liberalnu stranku te
Bloc Québécois - BQ) analizirao je profesor Sveučilišta Carleton u Ottawi, William Cross u poglavlju Party membership in Canada (50-65). Neke od ovih stranaka djeluju samo na federalnoj razini, neke ostvaruju veze sa sestrinskim provincijalnim strankama, dok je jedna regionalna, ali se natječe samo na federalnim izborima. Međutim svima je zajedničko tô da imaju članstvo kojemu ne postavljaju visoke uvjete za pristupanje. Svi članovi obvezni su samo plaćati članarinu te barem donekle biti privrženi vrijednostima stranke. Kanadski članovi stranaka mogu sudjelovati u unutarstranačkom procesu odlučivanja i deliberacije, selekcije kandidata i vodstva, te izboru delegata za nacionalne konferencije. Njihova prava na sudjelovanje u procesu oblikovanja politika svode se na davanje neobvezujućih mišljenja i prijedloga. Ovdje je i najviše zamjerki članova koji su, kako navodi Cross, izrazili želju značajnije utjecati na konačni izborni program. Kanadski su članovi također mahom sredovječni muškarci, boljeg imovinskog i obrazovnog statusa te izrazito neaktivni. Nešto više sudjeluju tek u aktivnostima kampanje.

Cross je uočio ciklusnu fluktuaciju u ukupnom broju članova u Kanadi. Brojevi doista dramatično rastu u razdoblju unutarstranačkih procesa selekcije i nominacije kandidata te se dramatično smanjuju u godinama općih izbora. To je djelomice posljedica prevladavanja pravila “jedan član - jedan glas” u kanadskim strankama. Crossova analiza pokazala je da su ključni motivi za učlanjenje - podrška politikama stranke, želja za utjecanjem na proces nominacije, te sudjelovanje u izboru vođe. Zaključno, Cross polemizira da će nedostatak mladih i žena sve više tjerati kanadske stranke da izvor svježih ideja potraže izvan stranaka. U Liberalnoj stranci simpati- 
zeri već imaju pravo sudjelovati u procesu oblikovanja politika putem online foruma.

Party membership in Denmark: Fluctuating membership figures and organizational stability (66-83) peto je poglavlje zbornika. U njemu profesorica politologije na Sveučilištu Kopenhagen Karina Kosiara-Pedersen analizira anketu koja je uključivala devet danskih stranaka. To su Zeleno-crvena alijansa (EL), Socijalistička narodna stranka (SF), Socijaldemokrati (SD), Socijalni liberali (RV), Kršćanski demokrati (KD), Liberali (V), Danska narodna stranka (DF), Konzervativna narodna stranka (KF) i Liberalna alijansa (LA). Danska ima stranački sustav koji proizvodi velik broj stranaka i izrazitu proporcionalnost $\mathrm{u}$ parlamentu, ali poput Kanade osim zakona koji reguliraju financiranje stranaka druge izvanjske regulacije o strankama nema. Uvjeti za učlanjenje su minimalni, a obveze se svode na plaćanje članarine. U svim strankama svim članovima dano je pravo sudjelovanja $\mathrm{u}$ procesu nominacije kandidata.

Danski unutarstranački kontekst pomalo je problematičan u komparativnom smislu. Naime, nije uvijek lako ustanoviti tko je de facto vođa stranke. Vođa stranke može obnašati jednu ili više od sljedećih funkcija: može biti vođa članske organizacije stranke, vođa parlamentarne frakcije i/ili premijer. $U$ KF-u i V-u vođu stranke bira parlamentarna frakcija, a članska organizacija ga formalno potvrđuje na sastancima koji se održavaju na godišnjoj razini. U RV-u su te dvije funkcije razdvojene, pa vođu parlamentarne frakcije biraju zastupnici, dok osobu koja predsjedava ukupnim članstvom biraju članovi stranke. EL nema vođu, već samo službenog glasnogovornika pri izboru kojeg presudnu ulogu imaju zastupnici stranke u parla- mentu. DF i LA vode njihovi osnivači, dok u SF-u i SD-u prakticiraju sustav “jedan član - jedan glas". Što se tiče prava na sudjelovanje u procesu donošenja odluka ona su ograničena, a simpatizeri nemaju nikakva formalna prava. Unatoč niskoj razini unutarstranačkih prava, istraživačica napominje da članovi nisu pokazali značajnije nezadovoljstvo takvom situacijom.

Danske stranke bilježe drastičan pad u broju članova, iako i dalje usporedno upisuju nove. Razlozi za učlanjenje većinom su ponovo ideološki, a nešto manje i procesni. Socio-demografska obilježja danskog stranačkog članstva očekivano su nereprezentativna u odnosu na opću populaciju. Tradicionalna ekonomska polarizacija stavova članstva po strankama vrlo je očita, a sječe ju samo u odnosu na jedno novije pitanje. Naime, u svim strankama postoji disperziranost stavova o pitanju podrške Europskoj uniji. Dodatno, stranke uglavnom imaju vrlo uske skupine aktivnih i neaktivnih ljudi, te one koji se aktiviraju samo s obzirom na pojedine aktivnosti.

U poglavlju Party membership in Germany: Rather formal, therefore uncool? (84-99) Tim Spier, profesor politologije na Sveučilištu u Siegenu i Markus Klein, profesor političke sociologije na Sveučilištu u Hanoveru istražili su članstva šest stranaka. Analiziraju tri catchall stranke (CDU, CSU, SPD) te nekoliko manjih stranaka $s$ ucjenjivačkim potencijalom (Liberalna slobodna demokratska stranka - FDP, Alijansa 90/Zeleni i Die Linke). Za razliku od prijašnjih slučajeva Njemačka ima vrlo opširno zakonodavstvo o političkim strankama koje utječe na konačno funkcioniranje stranaka i njihov odnos prema vlastitom članstvu, te koje podriva svaku organizacijsku inovaciju. Zakonodavstvo definira političke stranke kao organizacije člano- 
va pojedinaca, te ih obvezuje na uvođenje minimuma unutarstranačke demokracije i poštivanje svih ostalih zakona i ustavnih odredbi. Sve stranke dodatno su uvele neki oblik neobvezujućih plebiscitarnih mehanizama donošenja odluka.

Njemačke stranke su od uvođenja Zakona o političkim strankama iz 1967. godine obvezne objavljivati status članstva ako žele ostvariti prihod iz proračuna. Nepravilnosti se, navode autori, oštro kažnjavaju. Radi se o izrazito pouzdanim podacima o brojnosti članova. Za razdoblje od 1949. do 1990. Spier i Klein su koristili podatke proizišle iz projekta povjesničara Marie-Luise Recker i Klausa Tenfeldea. U 1949. godini postotni udio članova u biračkom tijelu iznosio je oko 4,7. Već 1961. pao je na 2,7, ali se 1973. godine vraća na 4,6 posto. Od 1990-ih godina podaci pokazuju trend stalnog opadanja, i apsolutnih brojeva članova, i postotnih udjela članova u društvu.

Empirijski nalazi anketa pokazali su da se pojedinci u njemačke stranke učlanjuju uglavnom motivirani kolektivnim, altruističnim i ekspresivnim motivima, dok su selektivni, odnosno materijalni razlozi najmanje izraženi. Demografski podaci su vrlo slični onima drugih država. Autori su uočili da velike catch-all stranke imaju članstvo sa znatno diverzificiranijim stavovima nego što je to slučaj sa manjim strankama. Što se tiče stranačkog aktivizma autori su izračunali da prosječan član neke njemačke male stranke utroši u prosječnom mjesecu sedam do osam sati na stranačke aktivnosti, a u catch-all strankama oko pet sati.

Članstvo izraelskih stranaka analiziralo je u poglavlju pod nazivom Party membership in Israel: The era of party primaries (100-116) dvoje istraživača izraelskog Instituta za demokraciju. Gideon Rahat je izvanredni profesor politologije na Hebrejskom sveučilištu u Jeruzalemu, a Ofer Kenig predavač na Aškenaskom akademskom koledžu. Njihova analiza definicije članstva obuhvaća sedam stranaka. Od toga za tri (Kadima, Laburisti i Likud), analizirana je dosad jedina anketa provedena nad izraelskim članstvom, ona iz 2010. godine. U Izraelu zakonodavstvo koje se odnosi na stranke propisuje obvezu da stranke unutar sebe urede propise za primitak novih i izbacivanje starih članova, te njihova prava i obveze. No, ostavlja im slobodne ruke da to učine onako kako smatraju da je najbolje. Dodatno, kako bi spriječilo manipulacije u razdoblju predizbora zakonodavstvo propisuje da nitko ne smije biti član više od jedne stranke, sve stranke moraju imati uređene registre članova, te da svaki član mora plaćati vlastitu članarinu. U velikom broju stranke tome još dodaju klasične uvjete članstva koji se tiču minimalne dobi, pristajanja uz stranačka načela, ekskluzivnost, a nekoliko stranaka traže i potpisanu izjavu o nekažnjavanju. Kolektivno članstvo ne postoji.

Rahat i Kenig pokazuju kako niti jedna analizirana izraelska stranka ne dopušta svim članovima sudjelovanje na stranačkim konferencijama. Doduše, 2012. godine Laburisti, Kadima i Meretz organizirali su posebne ideološke konferencije u svrhu oblikovanja političke platforme. Laburisti su poziv za sudjelovanjem uputili svim članovima, a druge dvije i svim zainteresiranim nečlanovima. Međutim, autori naglašavaju kako eksplicitno pravo sudjelovanja u oblikovanju stranačkih politika ne postoji niti u jednoj izraelskoj stranci. Svi članovi svih izraelskih stranaka imaju pravo biti birani i birati na izborima za stranačke i javne pozicije pod uvjetom da su članovi 
određeno vrijeme. Četiri stranke također trenutno omogućuju izbor predsjednika stranke putem izravnih predizbora, dok je Meretz to pravo imala u prošlosti. Većina članova predizbore smatra najboljom metodom za odabir kandidata i vođa, a većina podržava opciju uvođenja otvorenih predizbora.

Predizbori imaju i jedan neizravni, pozitivni učinak na točnost podataka o brojevima članova. Stranke prije svakih predizbora objavljuju popise članova koji ostvaruju pravo sudjelovanja u njima. Analizirajući pet vremenskih točaka u razdoblju od 30 godina Rahat i Kenig ustanovili su kako izraelske stranke bilježe vrlo strm pad u broju članova u odnosu na izborno tijelo, $s$ tek blagim porastom u 2012. godini. Uz to, predizbori uzrokuju sezonske fluktuacije - broj članova raste prije i opada nakon njih.

Očekivano, i izraelski članovi najviše su navodili ideološke, a najmanje osobne motive kao razloge za učlanjenje. Više od polovine izjavilo je da se učlanilo zato da podrže svog kandidata na predizborima. Socio-ekonomska obilježja izraelskih članova ista su kao i u prijašnjim poglavljima, s dodatkom vrlo snažne polarizacije na religijskoj osnovi. Sekularni Židovi podržavaju mahom lijeve, a religiozni mahom desne stranke. Shodno tome, najviše religioznih članova moguće je pronaći u Likudu, zatim centrističkoj Kadimi, a manjinu među Laburistima. Analiza je uključila i ispitivanje stavova članstava prema unutarnjim odnosima moći i općenito se može zaključiti kako izraelski članovi većinom podržavaju unutarstranačku disciplinu. Oko 60 posto ispitanika vjeruje da vođa mora donositi konačne odluke ako unutar stranke postoji neslaganje. Može se zaključiti da je ovo poglavlje potvrdilo tezu o pasivnom članstvu. Visoke razine participacije nisu uočene čak ni kod sudjelovanja na predizborima.

Osmo poglavlje, Party membership in Italy (117-133), priredile su Giulia Sandri, Antonella Seddone i Giorgia Bulli. Sandri je profesorica politologije na Katoličkom sveučilištu Lille, Bulli profesorica politologije na Sveučilištu u Firenci, a Seddone postdoktorantica Sveučilišta u Cagliariju. Uvjete za članstvo, prava i obveze analizirale su u pet stranaka, a karakteristike članova u trima PD (socijaldemokrati), M5S (populisti) i SEL (lijevo-radikalna stranka). U Italiji izvanjski propisi nadređeni unutarnjim dokumentima stranaka svode se na zakone o stranačkom financiranju i naknadama nakon izbora, te na ustavnu odredbu iz članka 49. koja govori o demokratskoj funkciji političkih stranaka kao spojnici između društva i države. Uvjeti za članstvo uvelike se poklapaju s uvjetima u drugim državama, s izuzetkom M5S-a koja ne traži plaćanje godišnje članarine. M5S je i jedina stranka koja ne traži od članova složnost u vezi s javnim politikama i izbornim programom. Autorice navode kako je većina stranaka uvela u statute institut simpatizera ili pristaša koje prije svega koriste kao siguran izvor glasova. Međutim, u PD-u oni imaju i konkretna prava sudjelovanja u deliberacijskim i odlučivačkim procesima. Samo dvije stranke omogućuju svim članovima sudjelovanje na konferencijama. U M5S-u sva se participacija odvija online, dok konferencije ostalih stranaka čine delegati. Osim toga, niti jedna stranka ne omogućuje svojim članovima sudjelovanje u izboru izvršnih organa stranke, a izravno odlučivati o politikama i izbornim programima mogu samo članovi PD-a i M5S-a.

U Italiji, navode autorice, postoji duga tradicija bilježenja kretanja u brojevima članova, a za koju je najzaslužniji 
Istituto Cattaneo Sveučilišta u Bolognji. Analiza tih podataka pokazuje kako su vrlo visoki brojevi članova (kao postotnog udjela u biračkom tijelu) u talijanskim strankama ostali stabilni tijekom više od 40 godina. Od 1948. do 1987. godine kretali su se $\mathrm{u}$ rasponu od 11 do 14 posto. Tek ranih 1990-ih godina prelaskom u Drugu Republiku dolazi do drastičnog pada na iznos od tek 3 posto. Blagi rast ponovno je nastupio 2008. godine (6 posto), što Italiju još uvijek pozicionira na prvo mjesto tadašnjih zemalja članica Europske unije.

Sandri, Seddone i Bulli pokazale su da su glavni motivi za učlanjenje u talijanske stranke ideološke prirode i da je uglavnom riječ o starijim, visoko obrazovanim muškarcima, nešto manje religioznima u odnosu na opću populaciju. Nešto više mladih i nešto više nezaposlenih članova autorice su pronašle u M5S, dok je nešto više umirovljenika u PD-u. Očekivano, članovi dviju lijevih stranaka i po stavovima se pozicioniraju na lijevom spektru, dok su članovi M5S-a bliže desnom centru, a među njima je i jače izražena heterogenost stavova. U pogledu sudjelovanja stranke pokazuju slične, relativno visoke razine aktivnosti članova, ali drugačije oblike. Članovi PD-a i SEL-a aktivniji su u konvencionalnim stranačkim aktivnostima, dok su u M5S članovi skloniji selektivnije sudjelovati, naročito u prosvjedima i bojkotima te putem novih tehnologija.

Analizu nizozemskog stanja u poglavlju Party membership in the Netherlands (134-150) izložili su Josje den Ridder, istraživačica Nizozemskog instituta za društvena istraživanja, te Joop van Holsteyn i Ruud Koole, profesori politologije na Sveučilištu u Leidenu. U Nizozemskoj prema zakonodavstvu koje regulira financiranje stranaka, članom se smatra osoba koja godišnje uplaćuje više od 12 eura članarine i koja prema tome ima određena prava i obveze. Isti zakon propisuje da politička stranka, želi li primiti sredstva iz državne blagajne, mora imati najmanje tisuću pojedinačnih članova. S obzirom na to da druge regulacije nema, stranka može imati i samo jednog člana (poznat je slučaj Slobodarske stranke Geerta Wildersa). Ipak, autori naglašavaju da većina relevantnih stranaka jesu članske organizacije.

Zanimljivo je da gotovo sve stranke dopuštaju dvostruko članstvo, s time da se članstvo u jednoj stranci ne može kombinirati s pozicijom kandidata ili političara u nekoj drugoj stranci. Mnoge nizozemske stranke omogućuju upis u registar simpatizera stranke, a neke od toga već i odustaju. Neke stranke omogućile su pravo izravnog izbora kandidacijskih lista, selekciju glavnog tajnika (odnosno vođe stranke u nizozemskom kontekstu), te izravni utjecaj na izborni program. Ostale stranke imaju vrlo različite oblike unutarnjeg donošenja odluka, ali očekivano najveći utjecaj članovi uglavnom imaju neizravno, putem izabranih delegata.

Za prikaz promjena u ukupnom broju članova autori su koristili longitudinalne podatke Dokumentacijskog centra za nizozemske političke stranke koji ih prikuplja i objavljuje na godišnjoj bazi. U iznosima omjera apsolutnih brojeva i ukupnih birača vidljiv je drastični pad u razdoblju od 1960. do 1971. godine, nakon čega se taj pad znatno usporava. Od ranih 1990-ih do 2012. godine iznosi drže konstantnu od oko 150 tisuća članova, iako autori navode više povijesno važnih događaja koji su i u tom razdoblju unosili turbulencije u registre članstava.

Ključni nalazi ovog poglavlja odnose se na podatke dobivene $\mathrm{u}$ istraživanju provedenom 2008. godine na članstvu 
sedam stranaka. Karakteristike članova nisu puno drugačije od onih u drugim državama. U pogledu stavova autori nude nekoliko općih zaključaka. Većina članova smatra kako socioekonomske nejednakosti nizozemskog društva treba smanjivati; manja većina smatra kako bi se etničke manjine trebale u potpunosti prilagoditi nizozemskoj kulturi; gotovo svi se slažu kako bi država morala biti stroža prema kriminalu. Naposljetku i unutar samih stranaka postoji određeni stupanj disperziranosti stavova.

Party membership in Norway: Declining but still viable? (151-168) prikazao je Knut Heidar, profesor politologije Sveučilišta u Oslu. On analizira sedam stranaka - dvije iz socijalističkog bloka, četiri iz nesocijalističkog bloka i jednu desno-populističku. Izuzev obveze plaćanja članarine i odredbi koje uređuju mogućnost isključenja iz stranke zbog nelojalnog ponašanja, u statutima stranaka nema drugih eksplicitno navedenih obveza. Općenito, uvjeti za članstvo ne odstupaju previše od prosječnih uvjeta u drugim demokracijama. Formalno mnoge norveške stranke omogućuju organiziranje referenduma, ali Heidar napominje kako to nije raširena praksa.

Rekonstrukcija brojevnog stanja norveškog članstva pokazuje kako pad u broju članova u Norveškoj nije dramatičan. Rezultati analize norveškog članstva pokazali su očekivane rezultate. Uglavnom su to, dakle, stariji muškarci boljeg profesionalnog i obrazovnog statusa i učlanili su se motivirani ideologijom. Ipak, znatno su aktivniji u usporedbi s članovima drugih zemalja. Zanimljivo je i to da čak 42 posto članova pripada skupini ekonomski neaktivne populacije (studenti, umirovljenici, osobe zaposlene kod kuće i primatelji socijalne pomoći).
Pretposljednje poglavlje Party membership in Britain: A minority pursuit (169-185) obrađuje tri velike (Konzervativnu, Laburističku i Liberalne demokrate) i dvije manje (Škotsku nacionalnu stranku - SNP i Zelene) britanske stranke. Lynn Bennie, profesorica politologije Sveučilišta u Aberdeenu, analizirala je više posljednjih istraživanja stranačkog članstva u pojedinim strankama, jer, kako navodi, u Velikoj Britaniji nikad u isto vrijeme nisu istraživane dvije stranke. Vremensko razdoblje obuhvaća podatke nastale tijekom 12 godina (od 1997. do 2009. godine). Iako je njezina analiza stoga vremenski neusklađena, otkrila je trendove slične onima u drugim državama. Ključni uvjeti za članstvo su plaćanje članarine, ekskluzivnost i slaganje s politikama stranke. Sve analizirane britanske stranke omogućuju upis u stranku na svim teritorijalnim razinama i sve su otvorile građanima opciju upisa u registar pristaša. Iako uglavnom zadovoljni procesima unutarstranačke demokracije i mogućnostima za sudjelovanje, ako je suditi po nalazima ovog poglavlja članovi britanskih stranaka još su manje aktivni nego članovi stranaka u drugim državama. Naime, većina članova britanske stranke u prosječnom mjesecu uopće ne posvećuje vrijeme aktivnostima stranke.

Članovi su i ovdje većinom stariji muškarci, često umirovljenici. Uglavnom se identificiraju kao pripadnici srednje ili radničke klase, te su manje religiozni od opće populacije. Ipak je moguće primijetiti kako se većina britanskih stranaka približila rodnoj ujednačenosti, pa žene čine barem oko 40 posto članstva. Sve stranke imaju delegatske konferencije, dok samo Zeleni eksplicitno daju članovima pravo sudjelovanja na godišnjim konferencijama posvećenima oblikovanju politika. Po- 
daci o brojnosti članstva pokazuju sustavno opadanje još od 50-ih godina 20. stoljeća. Ipak neke stranke (primjerice SNP i Stranka neovisnosti Ujedinjenog Kraljevstva) bilježe rast u članstvu.

U zaključnom poglavlju Conclusion: Members and activists of political parties in comparative perspective (186-202) urednice Anika Gauja i Emilie van Haute još jednom naglašavaju važnost knjige za istraživačko područje političkih stranaka. Zaključno donose i pregled najznačajnijih nalaza i preporuka proizišlih iz knjige. Opći zaključak zbornika je da stranke još uvelike drže članstvo vrijednim čimbenikom, ponekad ih privlačeći kroz mehanizme neformalnih oblika sudjelovanja. Urednice ističu da je ultimativna svrha zbornika otvoriti prostor za nova dubinska istraživanja u državama koje dosad nisu bile uključene u analize stranačkog članstva.

Knjiga će biti najkorisnija istraživačima i studentima komparativne politike, posebno onima s izraženim zanimanjem za pitanja predstavništva, sudjelovanja, političkih stranaka, izbora i unutarstranačkih procesa donošenja odluka. Njezina prava vrijednost jest u vrelu empirijskih podataka o pojedinim strankama, te statističkih i metodoloških napomena, koje je naprosto bilo nemoguće ovdje prikazati. Oni među ostalim uključuju analize iznosa članarina, specifičnih uvjeta za članstvo, mehanizama unutarstranačke demokracije, metodološke specifikume pojedinih anketa $\mathrm{i}$ njihove analize i još mnogo toga. Nedostatci zbornika mogu se smatrati porođajnim mukama pokušaja stvaranja sustavne analize stranačkih članstava u čak deset zemalja. Najveće prepreke za komparaciju među zemljama predstavljaju primjeri Španjolske i Velike Britanije. U primjeru Španjolske zaključci se odnose samo na delegate, ne i ukupno članstvo, dok kod Velike Britanije zaključivanje ometa činjenica da su istraživanja provođena u različitim strankama u različitim vremenskim razdobljima te putem nejednakih upitnika. Možda je glavna mana zborniku ipak to što ne sadrži analizu članstva niti jedne postkomunističke države. U duhu zaključnih poruka urednica, istraživači političkih stranaka i stranačkog članstva u postkomunističkim državama morali bi taj nedostatak shvatiti kao poticaj da se pokušaju prihvatiti istog posla.

Kristina Ćelap 